\title{
Prone positioning as an emerging tool in the care provided to patients infected with COVID-19: a scoping review*
}

\author{
Marília Souto de Araújo ${ }^{1}$ \\ (D) https://orcid.org/0000-0002-6975-8683 \\ Marina Marisa Palhano dos Santos ${ }^{1}$ \\ (iD) https://orcid.org/0000-0003-3536-3728 \\ Carlos Jordão de Assis Silva ${ }^{1}$ \\ (1D) https://orcid.org/0000-0002-9575-9030 \\ Rejane Maria Paiva de Menezes ${ }^{1}$ \\ (1D) https://orcid.org/0000-0002-0600-0621 \\ Alexsandra Rodrigues Feijão ${ }^{1}$ \\ (D) https://orcid.org/0000-0002-8686-9502 \\ Soraya Maria de Medeiros ${ }^{1}$ \\ (D) https://orcid.org/0000-0003-2833-9762
}

Objective: to describe scientific evidence regarding the use of prone positioning in the care provided to patients with acute respiratory failure caused by COVID-19. Method: this is a scoping review. PRISMA Extension for Scoping Reviews was used to support the writing of this study. The search was conducted in seven databases and resulted in 2,441 studies, 12 of which compose the sample. Descriptive statistics, such as relative and absolute frequencies, was used to analyze data. Results: prone positioning was mainly adopted in Intensive Care Units, lasted from a minimum of 12 up to 16 hours, and its prescription was based on specific criteria, such as $\mathrm{PaO}_{2} / \mathrm{FiO}_{2}$ ratio, oxygen saturation, and respiratory rate. The most prevalent complications were: accidental extubation, pressure ulcer, and facial edema. Decreased hypoxemia and mortality rates were the main outcomes reported. Conclusion: positive outcomes outweighed complications. Various cycles of prone positioning are needed, which may cause potential work overload for the health staff. Therefore, an appropriate number of trained workers is necessary, in addition to specific institutional protocols to ensure patient safety in this context.

Descriptors: Coronavirus Infections; Respiratory Tract Infections; Adult Respiratory Distress Syndrome; Prone Position; Nursing; Critical Care.

\section{How to cite this article}

Araújo MS, Santos MMP, Silva CJA, Menezes RMP, Feijão AR, Medeiros SM. Prone positioning as an emerging tool in the care provided to patients infected with COVID-19: a scoping review. Rev. Latino-Am. Enfermagem. 2021;29:e3397. [Access ]; Available in: month day year DOI: http://dx.doi.org/10.1590/1518-8345.4732.3397. 


\section{Introduction}

During December 2019, the city of Wuhan, China witnessed an outbreak of pneumonia of unknown cause. In January 2020, Chinese scientists isolated the causative agent, the novel Coronavirus (SARSCoV-2). In February of the same year, the World Health Organization (WHO) called this pathology COVID-19(1).

The disease spread rapidly and became a concern due to the large number of individuals who were contaminated and died worldwide. A total of 19,266,406 cases and 718,530 deaths caused by COVID-19 were confirmed up to August $7^{\text {th }}, 2020^{(2)}$. In Brazil, 2,967,064 cases and 99,702 deaths had been confirmed until the same date ${ }^{(2)}$.

COVID-19 is characterized by a broad clinical spectrum, encompassing asymptomatic infection, mild disease of the upper respiratory tract, and severe viral pneumonia with respiratory failure, multiple organ failure, and even death ${ }^{(3)}$. The most common symptoms at the onset of COVID-19 are fever, cough, and fatigue, while other symptoms include dyspnea, headache, hemoptysis, anosmia, dysgeusia, and diarrhea. In its most severe manifestation, clinical characteristics indicate the development of Acute Respiratory Discomfort Syndrome (ARDS), acute cardiac injury, and thrombotic phenomena(4). One study ${ }^{(5)}$ confirms that the most common symptoms at the onset of the disease include fever ( $98 \%)$ and cough (76\%); dyspnea was found in $55 \%$ of the patients. Complications inherent to the most severe form of the disease affected $29 \%$ of the patients, who developed ARDS, requiring critical care.

According to data of the Chinese Center for Disease Control and Prevention, which included 44,500 people with a confirmed diagnosis of the SARS-CoV-2 infection, $14 \%$ of the cases were affected by the most severe form of the disease, while those with a critical condition, presenting respiratory failure and consequently requiring mechanical ventilation, totaled $5 \%{ }^{(6)}$.

Currently, the early intubation of patients with COVID-19 is recommended, especially among those with severe hypoxemia, characterized by a $\mathrm{PaO}_{2} / \mathrm{FiO}_{2}$ ratio $<200 \mathrm{mmHg}$, according to the Berlin criteria for $\operatorname{ARDS}^{(7)}$. The literature recommends Prone Positioning (PP) associated with mechanical ventilation for patients presenting refractory hypoxemia or respiratory failure. Prone ventilation consists of providing mechanical ventilation with the patient in prone position. This is an additional therapy to treat severe hypoxemia caused by $\operatorname{ARDS}^{(8)}$.

The Prone Positioning in Severe Acute Respiratory Distress Syndrome (PROSEVA) ${ }^{(9)}$ trial provided scientific evidence of the effectiveness of the PP in the treatment of ARDS. The results of the randomized clinical trial conducted with 466 participants indicate that its early adoption (between 12 and 24 hours after the diagnosis of ARDS) for prolonged periods significantly decreased mortality in the intervention group. The rate of mortality in 28 days was $16 \%$ in the prone group and $32.8 \%$ in the control group ( $<<0.001)$, and $23.6 \%$ and $41.0 \%$, respectively, in a 90-day period $(p<0.001)^{(9)}$.

Considering that ARDS is the most severe complication of COVID-19, accounting for considerably high mortality rates, this study's objective is to describe scientific evidence of the use of PP in the care provided to patients with acute respiratory failure caused by COVID-19.

\section{Method}

This is a scoping review, which is characterized by the objective of mapping the main concepts of a field of knowledge, in this case, the Nursing field, and examining the extent, scope, and nature, in addition to summarizing and disseminating the results of studies, and identifying existing research gaps ${ }^{(10)}$.

The recommendations of the Joanna Briggs Institute Reviewer's Manual(11) were adopted. Additionally, the instrument titled PRISMA Extension for Scoping Reviews (PRISMA-SCR) was used in the elaboration of this study. This instrument is divided into seven domains and 22 items, providing recommendations regarding the title, abstract, introduction, method, results, discussion, conclusion, and financial support.

The search was conducted in the following databases: PubMed/MEDLINE, PMC, Science Direct, Web of Science, SCOPUS, Scientific Electronic Library Online (SciELO), and Google Scholar, between April and May 2020.

Scientific studies and other relevant articles available in the gray literature addressing the use of PP in the care provided to patients with acute respiratory failure caused by COVID-19 were considered.

The full texts of studies available free of charge and which answered the study question were included. Primary studies, systematic reviews, meta-analyses, guidelines, descriptive reports, official communications of governmental institutions, and studies addressing 
adult individuals were included without any language restrictions.

Studies that did not answer the study question or the objective of which was not PP related to respiratory failure caused by COVID-19 were excluded. Only studies published from December 2019 onwards were considered. The reason this timeframe was chosen is that this is when this pathology emerged and was identified.

The search process took place at three different points in time. First, a search was conducted in the Latin American and Caribbean Literature in Health Sciences (LILACS), Open Science Framework, and Cumulative Index to Nursing and Allied Health Literature (CINAHL) to identify titles and studies similar to that proposed here. No studies answering the study question were found in any of the databases. After identifying the originality of the topic and the need to produce evidence, we proceeded to the data collection.

Two researchers with a Master's degree conducted an independent and blinded search. The starting time was determined and the search ended only when the possibilities of crossing were exhausted. Finally, the gray literature was consulted at a third point in time to identify manuals, consensus, and guidelines that potentially answered the research question. The question was established using the PCC strategy, according to the following.

P (Population) - Patients infected with COVID-19;

$C$ (Concept) - Prone positioning;

C (Context) - Hospital care.

Hence, the following question was established: "What is the evidence available concerning the use of prone positioning in the care provided to patients with acute respiratory failure caused by COVID-19?".

The following descriptors indexed in Medical Subject Headings ( $\mathrm{MeSH})$ were used in the search: 1. COVID-19; 2. new coronavirus; 3. 2019 nCOV; 4. SARS-CoV-2; 5. Severe acute respiratory syndrome coronavirus $2 ; 6$. Prone position. The terms that would permit a broad search strategy regarding the subject, were used, namely: ("COVID-19" OR "new coronavirus" OR "2019 nCoV" OR "SARS-CoV-2" OR "severe acute respiratory syndrome coronavirus 2") AND "prone position".

After determining the descriptors and establishing the aforementioned strategy, the search in the databases/repositories was initiated. The databases were accessed through the CAPES periodicals portal, using the CAFe platform, a service that facilitates digital access through the use of a login registered at the university. An external search was also conducted in the gray literature, as recommended by the Reviewer's Manual(11).

After defining the sample, a protocol was adapted from the Cochrane Data collection form to extract data. The form addressed the following: country, year of publication, study objective, study design, eligibility criteria, institution where the intervention was conducted, population, methods used to implement the intervention, measures adopted to assess the intervention, outcomes, and complications accruing from the intervention.

The following information was extracted from the selected studies to answer the study question: 1) institution where the prone intervention was adopted; 2) criteria to adopt the PP; 3) PP duration; 4) main outcome and secondary outcome, and; 5) complications.

Note that the studies were classified in terms of levels of evidence, based on the Joanna Briggs Institute Levels of Evidence(11): Level 1 - Experimental designs: 1.a) Systematic review of Randomized Controlled Trials; 1.b) Systematic review of randomized controlled trials, and other study designs; 1.c) Randomized controlled trials; $1 . d)$ Pseudo-randomized controlled trials; Level 2 - Quasi-experimental designs: 2.a) Systematic review of quasi-experimental studies; 2.b) Systematic review of quasi-experimental and other lower study designs; 2.c) Quasi-experimental prospectively controlled study; 2.d) Pre-test and post-test or historic/retrospective control group study; Level 3 - Observational - Analytic Designs: 3.a) Systematic review of comparable cohort studies; 3.b) Systematic review of comparable cohort and other lower study designs; 3.c) Cohort study with control group; 3.d) Case - controlled study; 3.e) Observational study without a control group; Level 4-Observational-Descriptive Studies: 4.a) Systematic review of descriptive studies; 4.b) Cross-sectional study; 4.c) Case series Level; 4.d) Case study; Level 5 - Expert Opinion and Bench Research: 5.a) Systematic review of expert opinion; 5.b) Expert consensus; 5.c) Bench research/single expert opinion.

A descriptive analysis of data was performed, using relative and absolute frequencies. Data were characterized and results are presented in tables, figures, and graphs. Because this study does not 
involve human subjects, it did not require submission and approval by an Institutional Review Board. Additionally, there is minimum risk involved, as it is not experimental. Law No. 9,610/98 was fully complied with, intending to preserve and respect the ideas, concepts, and definitions adopted by the authors of the primary studies included in this review.

\section{Results}

Twelve of the 2,441 studies assessed were included in the final sample, as presented in Figure 1.

The sample is characterized by studies in the medical field (92\%), predominantly conducted in the United States (33\%), and published in 2020 (100\%). As for the method adopted, reviews (42\%) and expert consensus (42\%) predominated.

Figure 2 presents the characterization of the studies included in the final sample according to the country of origin, study design, objective, main conclusions, and level of evidence according to the Joanna Briggs Institute.

The results show that $83 \%$ of the studies used PP among patients affected with severe acute respiratory failure caused by COVID-19 in Intensive Care Units, while the remaining studies proposed its adoption among clinically stable patients hospitalized in clinical wards.

The $\mathrm{PAO}_{2} / \mathrm{FO}_{2}$ ratio, oxygen saturation, and respiratory rate were the criteria most studies (92\%) adopt to support decision-making concerning the implementation of PP. Gasometry parameters $\left(\mathrm{FiO}_{2}, \mathrm{pH}\right.$, $\mathrm{pCO}_{2}, \mathrm{pO}_{2}$ e $\mathrm{HCO}_{3}$ ) were also adopted (17\%).

There was disagreement regarding the duration of PP, though most studies (58.3\%) suggest a period from 12 to 16 hours (Figure 3 ).

Of the studies composing the sample, $67 \%$ report complications in the use of PP, the most frequent of which were: accidental extubation (78\%), pressure ulcers (50\%), and facial edema (50\%) (Figure 4 ).

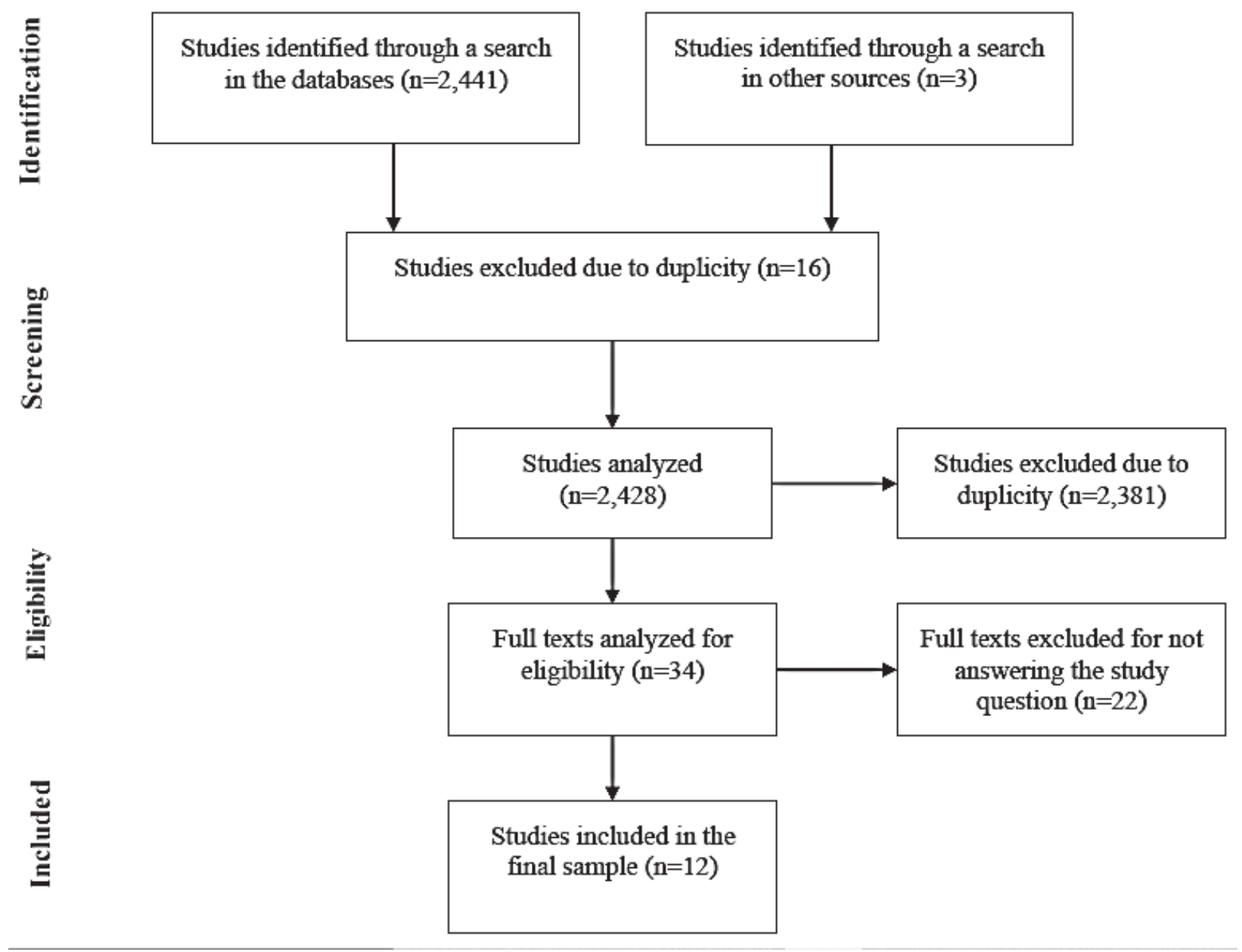

Figure 1 - Flowchart of the study selection in this scoping review 


\begin{tabular}{|c|c|c|c|c|c|}
\hline ID $^{*}$ & Country & Method & Objective & Main conclusions & LE $^{\dagger}$ \\
\hline $\mathrm{A} 1^{(12)}$ & USA & Case study & $\begin{array}{l}\text { To verify the effect of prone } \\
\text { positioning in one patient who tested } \\
\text { positive for SARS-CoV-2. }\end{array}$ & $\begin{array}{l}\text { PP is a vital part of the management plan and should } \\
\text { be adopted early on to decrease mortality. }\end{array}$ & $4 d$ \\
\hline $\mathrm{A} 2^{(13)}$ & China & Expert consensus & $\begin{array}{l}\text { Establish guidelines to work with } \\
\text { patients infected with 2019-nCoV. }\end{array}$ & $\begin{array}{l}\text { If a patient who tested positive for COVID-19 develops } \\
\text { ARDS, the adoption of invasive mechanical ventilation } \\
\text { combined with prone positioning is necessary. }\end{array}$ & $5 b$ \\
\hline $\mathrm{A} 3^{(14)}$ & Canada & Expert consensus & $\begin{array}{l}\text { Serve as the basis to optimize } \\
\text { supportive care for patients with } \\
\text { COVID-19. }\end{array}$ & $\begin{array}{l}\text { The implementation of PP is strongly recommended } \\
\text { for adult patients with COVID-19, though it requires } \\
\text { sufficient human resources and appropriate knowledge. }\end{array}$ & $5 b$ \\
\hline $\mathrm{A} 4^{(15)}$ & $\begin{array}{l}\text { Saudi } \\
\text { Arabia }\end{array}$ & Narrative review & $\begin{array}{l}\text { Describe the management of patients } \\
\text { with ARDS caused by COVID. }\end{array}$ & $\begin{array}{l}\text { Prone positioning, implemented among patients } \\
\text { with severe ARDS, was associated with improved } \\
\text { oxygenation, which was sustained after returning to the } \\
\text { supine position. }\end{array}$ & $\mathrm{n} / \mathrm{e}^{\ddagger}$ \\
\hline $\mathrm{A} 5^{(16)}$ & Italy & Prospective cohort & $\begin{array}{l}\text { Report the experience of a hospital } \\
\text { with patients with } \\
\text { COVID-19. }\end{array}$ & PP is suggested as an early treatment for COVID- 19. & $3 c$ \\
\hline$A 6^{(17)}$ & Brazil & Expert consensus & $\begin{array}{l}\mathrm{PP} \text { in the treatment of acute } \\
\text { respiratory distress in COVID-19. }\end{array}$ & $\begin{array}{l}\text { Even though PP is a resource that improves } \\
\text { oxygenation, caution is recommended when } \\
\text { prescribing this positioning during the COVID-19 } \\
\text { pandemic. }\end{array}$ & $5 b$ \\
\hline $\mathrm{A} 7^{(18)}$ & $\begin{array}{l}\text { United } \\
\text { Kingdom }\end{array}$ & Expert consensus & $\begin{array}{l}\text { Develop a flowchart to identify the } \\
\text { benefits of prone positioning among } \\
\text { patients with } \\
\text { COVID-19. }\end{array}$ & $\begin{array}{l}\text { Given the potential of PP to improve the oxygenation of } \\
\text { patients with COVID-19, its use is recommended for all } \\
\text { suitable and conscious patients in the ward. }\end{array}$ & $5 b$ \\
\hline $\mathrm{A} 8^{(19)}$ & USA & Literature review & $\begin{array}{l}\text { Describe the role of PP among } \\
\text { patients with } \\
\text { COVID-19. }\end{array}$ & $\begin{array}{l}\text { The prone positioning can contribute to decrease } \\
\text { mortality if implemented in the first hours after the } \\
\text { manifestation of the disease. }\end{array}$ & $\mathrm{n} / \mathrm{e}^{\ddagger}$ \\
\hline $\mathrm{A} 9^{(20)}$ & Spain & Expert consensus & $\begin{array}{l}\text { Share information regarding the } \\
\text { treatment of patients infected with } \\
\text { COVID-19. }\end{array}$ & $\begin{array}{l}\text { The prone position improves the ventilation/perfusion } \\
\text { ratio and prognosis. Some complications should be } \\
\text { prevented though. }\end{array}$ & $5 b$ \\
\hline $\mathrm{A} 10^{(21)}$ & USA & Literature review & $\begin{array}{l}\text { Describe the clinical management of } \\
\text { respiratory complications caused by } \\
\text { COVID-19. }\end{array}$ & $\begin{array}{l}\text { PP improves the ventilation/perfusion ratio, contributing } \\
\text { to decrease mortality rates caused by the novel } \\
\text { Coronavirus. }\end{array}$ & $\mathrm{n} / \mathrm{e}^{\ddagger}$ \\
\hline $\mathrm{A} 11^{(22)}$ & USA & Literature review & $\begin{array}{l}\text { Disseminate a protocol regarding the } \\
\text { clinical management of patients with } \\
\text { sepsis caused by SARS-CoV- } 2 \text {. }\end{array}$ & $\begin{array}{l}\text { The use of a POP is recommended to place patients } \\
\text { in the prone position in all institutions. One should be } \\
\text { attentive to absolute counter-indications. }\end{array}$ & $n / e^{\ddagger}$ \\
\hline $\mathrm{A} 12^{(23)}$ & $\begin{array}{l}\text { Costa } \\
\text { Rica }\end{array}$ & Scoping Review & $\begin{array}{l}\text { Establish a guide for Nursing care } \\
\text { provided to patients with } \\
\text { COVID-19 in the prone position. }\end{array}$ & $\begin{array}{l}\text { The prone positioning is an efficient alternative in } \\
\text { the treatment of individuals with ARDS caused by } \\
\text { COVID-19. Therefore, professional management is } \\
\text { essential to provide quality nursing care to decrease } \\
\text { complications and adverse events. }\end{array}$ & $\mathrm{n} / \mathrm{e}^{\ddagger}$ \\
\hline
\end{tabular}

${ }^{*} \mathrm{ID}=$ Identification; ${ }^{+} \mathrm{LE}=$ Level of evidence; ${ }^{\ddagger} \mathrm{n} / \mathrm{e}=$ no evidence

Figure 2 - Characterization of the studies composing the study sample

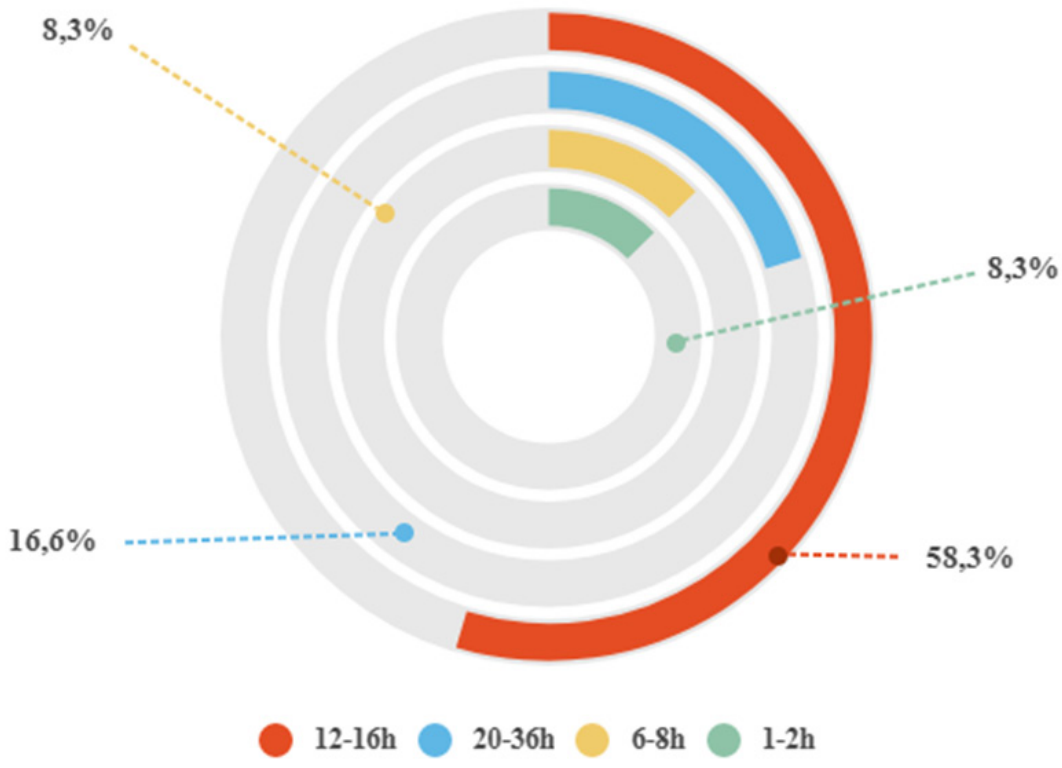

Figure 3 - Duration of PP among patients with severe acute respiratory failure caused by COVID-19 
60

Pressure ulcers

\section{- Accidental extubation}

Difficult venous access

Hemodynamic instability

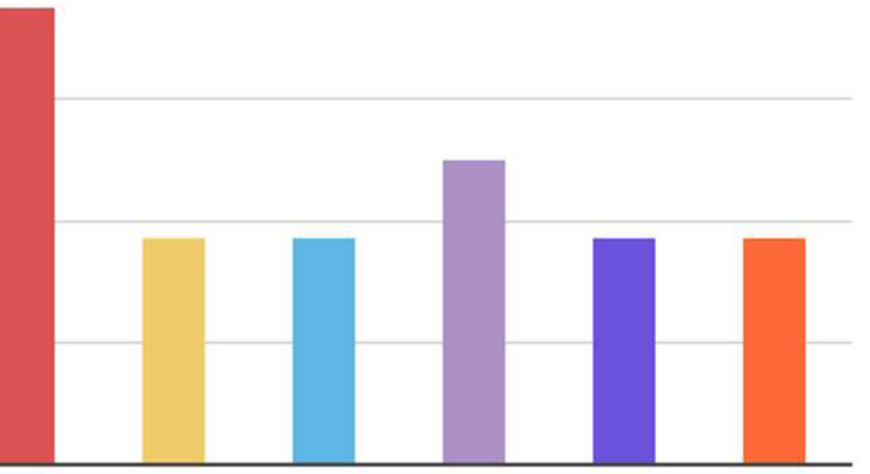

Corneal lesions

Brachial plexus injury

Facial edema

Figure 4 - Complications accruing from the use of PP among patients with severe acute respiratory failure caused by COVID-19

In addition to the aforementioned complications, there are other less frequent results, such as esophageal reflux, increased risk for pneumothorax and respiratory distress; increased risk for hemoptysis; tendency to hypersalivation and bruises in the perioral region.

Figure 5 presents the main primary and secondary outcomes identified in the studies composing the sample. Decreased hypoxemia, decreased mortality and improved pulmonary artery perfusion were the main outcomes from the adoption of PP in the studies.

Studies report that the early implementation of $\mathrm{PP}$, especially among patients receiving mechanical ventilation, is an efficient strategy to reverse severe hypoxemia, resulting in decreased mortality. Its prescription, however, should be precisely assessed and potential complications weighted.
Decreased hypoxemia

\section{Decreased mortality}

Improved pulmonary perfusion

Decreased pulmonary vascular resistance

\section{Reduction of alveolar collapse}

\section{Increased tidal volume}

Secretion mobilization

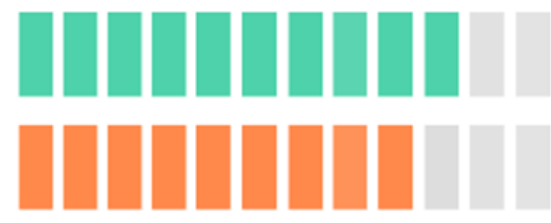

$83 \%$

$58.3 \%$

$33.3 \%$

$25 \%$

$8.3 \%$

$8.3 \%$

$8.3 \%$

Figure 5 - Main outcomes from the use of PP among patients with severe acute respiratory failure caused by COVID-19 


\section{Discussion}

The sample adopted in this study was mostly composed of studies developed in the United States of America (A1, A8, A10, A11), reviews (A4, A8, A10, A11, A12) and expert consensus (A2, A3, A6, A7, A9). The predominance of the United States is likely explained by its current status as the epicenter of the pandemic, with $4,932,510$ cases up to August $7^{\text {th }}, 2020^{(2)}$. Additionally, the USA ranks first in the number of scientific papers published from 2013 to 2018, which characterizes it as the world scientific hub(24).

As for the studies' level of evidence in relation to the methods adopted, reviews provide robust evidence regarding a given topic. Additionally, they are original studies that do not require approval by an Institutional Review Board, which speeds up the process of writing and publishing papers ${ }^{(25)}$. In turn, when there is a lack of experimental studies or even reviews, consensuses written by renowned experts or experts with confirmed experience can be used to support and provide evidencebased practice ${ }^{(26)}$.

The use of PP among patients hospitalized in ICUs is explained by the severity of their conditions ( $A 1$, A2, A3, A4, A5, A6, A8, A9, A10, A11, A12), with a low $\mathrm{PaO}_{2} / \mathrm{FiO}_{2}$ ratio, revealing respiratory distress and negatively affecting noble organs such as brain, heart, and kidneys. ARDS of viral etiology stands out due to its high mortality, equal to about $50 \%$ of the cases, and is characterized by pulmonary edema of cardiogenic origin, causing hypoxemia and the need for invasive ventilatory support(27).

Regarding the duration of prone positioning, recommendations vary but most studies recommend a minimum from 12 to 16 continuous hours (A2, A3, A4, A8, A9, A10, A11). The American Association of CriticalCare Nurses ${ }^{(28)}$ and the Associação de Medicina Intensiva Brasileira(29) (Brazilian Association of Intensive Care Medicine) recommend 16 hours of prone positioning for patients with ARDS receiving mechanical ventilation, a recommendation that is in line with this review's findings.

Regarding complications, even though prone positioning was found to decrease pressure on bony prominences commonly injured in the supine or lateral positions ${ }^{(30)}$, PP exerts pressure on the frontalis and orbicularis muscles, chin, humerus, thorax, pelvis, and knees, causing several related adverse events ${ }^{(31)}$. Additionally, such pressure causes a heterogeneous distribution of blood and lymph flow in the face, as well as tissue ischemia and consequent necrosis, which results in the undesirable outcomes "pressure ulcers" and "facial edema", identified in five of the studies in the sample (A2, A8, A9, A11, A12).
Direct pressure on the orbits, together with vascular changes, cause extraocular muscle impact, with the potential to culminate in conjunctival edema, bleeding, and even corneal injury, one of the complications that stands out in the sample (A9, A11, A12). A clinical trial reports that after ten minutes in the prone position, patients presented high intraocular pressure, as well as a greater risk of corneal ulceration. This type of damage may compromise eye function and require lifelong eye care, even though evidence shows that corneal abrasion and scleral wounds caused by prone positioning are generally self-limiting(32).

Additionally, PP may cause traction on the humerus, either on its flexion or extension, leading to increased intraneural venous pressure, local edema, and impairment in the axoplasmic transmission of the elements that compose the brachial plexus(33).

A case study of a patient placed in the prone position for a surgical procedure verified that, after five hours in this position, he developed brachial plexopathy. Studies suggest adopting measures such as cushions to reduce pressure on the pectoral muscles and prevent them from being pushed into the axillary fossa, pressing the plexus, as well as palpating the tendon of the pectoralis major muscle to monitor its tension(34-35).

Among complications, six studies report the occurrence of accidental extubation ( $A 2, A 6, A 7, A 9, A 11$, A12). This complication is facilitated due to the spatial configuration of the position in relation to the airways, which makes them dilate due to the gravitational action on the local anatomical structures. Therefore, patients in the prone position may present an increased risk of displacing and twisting the orotracheal tube (OTT), leading to extubation ${ }^{(36)}$.

Another study, the objective of which was to report experiences in a COVID-19 ICU, also reports accidental extubation as one of the potential complications in prone positioning used to treat ARDS(37). Therefore, studies ${ }^{(38-39)}$ recommend constant and vigilant monitoring of OTT and timely action when this problem occurs, as it may aggravate an already critical condition, imposing even greater risks on patients ${ }^{(38)}$.

Likewise, PP presents some peculiar hemodynamic challenges. One observational prospective study verified that compression of the abdomen during PP may restrict blood flow from the inferior vena cava, causing venous engorgement and consequent decrease in the cardiac output $^{(40)}$. In the context of a patient with severe acute respiratory failure caused by COVID-19, this may be a desired outcome to achieve decreased myocardial work and prevent cardiac factors associated with respiratory failure. The combination of arterial hypotension, increased intra-abdominal pressure, and hypovolemia in 
patients in the prone position may lead to poor perfusion to multiple systems and cause hemodynamic instability though, a complication reported in three studies in the sample (A8, A11, A12)(41).

Regarding the pathophysiological mechanism of COVID-19, in addition to acute respiratory distress syndrome, there are also acute kidney complications and multiple organ failure ${ }^{(37,42)}$. Therefore, many of these patients require extensive support encompassing varied procedures that require venous access. Nonetheless, as previously mentioned, pronation adopted in this circumstance to manage ARDS complicates obtaining venous access, as shown by studies A8, A9, and A11.

This finding is corroborated by a case report that used popliteal venous access to enable renal replacement therapy in a critical patient with COVID-19 who was in PP. This procedure was justified by the difficulty in finding another site to puncture the intravenous route ${ }^{(43)}$.

Therefore, the literature shows that PP improves gas exchange in approximately two-thirds of patients with ARDS because it works as a recruitment maneuver with long-term effects, which leads to improved oxygenation. This maneuver explores gravity and repositioning of the heart in the chest to recruit pulmonary perfusion ratio and arterial oxygenation ${ }^{(44)}$.

The prone position enables a redistribution of alveolar ventilation and perfusion. With a decrease in the effects of compression that favor atelectasis, pleural pressure is reduced, as well as transpulmonary pressures, and thus, alveolar recruitment can be achieved in atelectatic areas ${ }^{(44)}$. These PP mechanisms clarify the outcomes reported by the studies in the sample.

It is known that pulmonary involvement caused by the SARS-CoV-2 infection is uniform, causing an increase in lung volume, as a result of the edema, a result of the inflammatory process. Considering gravitational basilar reasoning, researchers ${ }^{(45)}$ used tomographic resources and verified that the dorsal part of the lungs suffers greater impact when in the supine position, caused by increased lung volume, which generates collapse among dependent regions.

A case study ${ }^{(46)}$ conducted with a patient infected with SARS-CoV-2 compared the tomography performed in the patient in the supine position versus prone position. The supine positioning revealed a significant increase in the extension and accentuation of opacities, with pulmonary consolidation and atelectasis of the right lower lobe. The tomography performed in the prone position showed partial recovery of the pulmonary parenchyma and a decrease in the previous pulmonary consolidations $^{(46)}$.

Pronation is a strategy that tends to decrease the impact caused by increased lung weight, caused by the edema, under important regions, enabling improved oxygenation $^{(47)}$, as discussed in studies $A 1, A 3, A 4, A 5$, A6, A7, A9, A10, A11, and A12. Additionally, studies(48-49) show an increase in tidal volume to be responsible for improved oxygenation in PP, which is in line with study A8.

Improved oxygenation is the effect most frequently expected and discussed in studies when PP is adopted. In addition to what we discussed previously, this effect also takes place due to a decrease in the various factors that contribute to alveolar collapse, such as redistribution of alveolar ventilation, reordering of perfusion, and reducing dorsal lung compression(47,50). Note that improved pulmonary perfusion is an outcome reported in studies A1, A4, A5, and A10.

The case study ${ }^{(12)}$ of a patient with severe acute respiratory failure caused by COVID-19 reports that, after 12 hours in the prone position, the patient progressed from the initial environmental $\mathrm{O}_{2}$ saturation of $85 \%$ to $95 \%$ at rest and $90 \%$ when walking. Clinical trials report that oxygenation is improved in the prone group when compared to a group of patients in the supine position, with an increased $\mathrm{PaO}_{2} / \mathrm{FiO}_{2}$ ratio(9,51).

In contrast, a study ${ }^{(52)}$ that analyzed the oxygenation of ten critical patients who tested positive for SARS-COV-2 and were intubated and receiving mechanical ventilation reports improved $\mathrm{PaO}_{2} / \mathrm{FiO}_{2}$ ratios in the supine position when compared to the long test of patients in the prone position $(p=0.034)$.

Another important aspect is the role that the position of the rib cage plays in transpulmonary pressure. In PP, the rib cage presents a rectangular format, which results in decreased alveolar collapse, according to study A8.

Additionally, it is known that the cardiac muscle plays an important role in the lungs when in normal physiological conditions. This effect in a patient with respiratory failure due to COVID-19 may be even more important due to an increase in the right cardiac chamber, secondary to pulmonary hypertension, and hypoxic vasoconstriction, which results in increased pulmonary vascular resistance (A2, A7, and A8).

Likewise, two studies show that PP promotes the mobilization of secretions, which may improve the oxygenation of patients ( $A 1$ and $A 2$ ). The reason is that PP enables improved drainage of secretion from the airways, which further promotes a reduction in the risk of respiratory infection associated with mechanical ventilation.

One study(53) reports that PP greatly impacts the cardiopulmonary physiology, being a useful maneuver accessible for most ICUs.

PP improves pulmonary mechanics and gas exchange and guidelines currently recommended it ${ }^{(54-55)}$. 
Therefore, PP should be considered in the initial stages of respiratory failure, considering that evidence suggests that the early implementation of prolonged ventilation in PP decreases mortality among patients with severe ARDS caused by COVID-19 (A1, A6, A7, A9, A10, and A11).

Thus, PP can improve oxygenation and compliance of the pulmonary system of patients with severe acute respiratory syndrome caused by COVID-19(56). It can also decrease mortality rates in the subgroup with severe ARDS and causes few complications when its positive outcomes are considered(57).

This study presents limitations such as a lack of studies in the sample with high levels of evidence, such as randomized clinical trials. This gap, however, is explained by the fact this is a recent disease, with little time for studies that require long follow-up periods.

This study's social contribution refers to an analysis of the most recent studies adopting PP among patients with respiratory failure caused by COVID-19, a disease of global repercussions, the impact of which in the health and economy spheres has caused profound changes in society. The results found here support the improvement of work processes in health and nursing, for consequent improvement of the care provided to the population.

As for its scientific relevance, this study contributes with an attempt to deepen the subject, aiming to fill this gap in the literature addressing the topic. Additionally, scoping reviews are useful to examine emerging evidence regarding topics that still lack robust evidence, as is the case of the novel Coronavirus.

\section{Conclusion}

This study's objective was to describe scientific evidence concerning the use of PP in the care provided to patients with acute respiratory failure caused by COVID-19. The sample was composed of 12 studies, which showed the use of PP, mainly in ICUs, with a duration from 12 to 16 hours.

The criteria used by the health staff to implement $\mathrm{PP}$ include the $\mathrm{PAO}_{2} / \mathrm{FiO}_{2}$ ratio, oxygen saturation, and respiratory rate. Complications caused by PP were also identified: accidental extubation, pressure ulcers, and facial edema were the most frequently reported.

The positive outcomes outweighed the complication though. Thus, considering the evident decrease in hypoxemia and mortality rates, its use is recommended for patients with respiratory failure caused by SARSCoV-2.

That said, sustained improvement in oxygenation requires various cycles of pronation, a factor that may potentially overload the work of the health staff. Indeed, the studies suggest that having an appropriate number of trained workers and specific institutional protocols to ensure patient safety in this context is required.

\section{References}

1. Zhonghua $L$, Xing $B$, Xue ZZ. The epidemiological characteristics of an outbreak of 2019 novel coronavirus diseases (COVID-19) in China. Zhonghua Liu Xing Bing Xue Za Zhi. 2020;41(2):145-51. doi: 10.3760/cma.j.is sn.0254-6450.2020.02.003

2. Organização Pan-Americana da Saúde. Folha informativa - COVID-19 (doença causada pelo novo coronavírus). [Internet]. 2020 [Acesso 14 jul 2020]. Disponível em: https://www.paho.org/bra/index. php?option $=$ com_content\&view $=$ article $\& i d=6101$ : covid 19\&Itemid $=87$

3. Zhou F, Yu T, Du R, Fan G, Liu Y, Liu Z, et al. Clinical course and risk factors for mortality of adult inpatients with COVID-19 in Wuhan, China: a retrospective cohort study. Lancet. 2020;395(10229):1054-1062. https://doi. org/10.1016/S0140-6736(20)30566-3

4. Rothan HA, Byrareddy SN. The epidemiology and pathogenesis of coronavirus disease (COVID-19) outbreak. J Autoimmun. 2020;109(102433). doi: https://doi.org/10.1016/j.jaut.2020.102433

5. Huag C, Wang Y, Li X, Ren L, Zhao J, Hu Y, et al. Clinical features of patients infected with 2019 novel coronavirus in Wuhan, China. Lancet. 2020;395(10223):497-506. doi: https://doi.org/10.1016/S0140-6736(20)30183-5

6. Cascella M, Rajnik M, Cuomo A, Dulebohn SC, Di Napoli R. Features, Evaluation and Treatment Coronavirus (COVID-19). [Internet]. 2020 [cited Jul 14, 2020]. Available from: https://www.ncbi.nlm.nih.gov/books/ NBK554776/

7. Möhlenkamp S, Thiele H. Ventilation of COVID-19 patients in intensive care units. Herz. 2020. doi: https:// doi.org/10.1007/s00059-020-04923-1

8. Sud S, Friedrich JO, Taccone P, Polli F, Adhikari NK, Latini $R$, et al. Prone ventilation reduces mortality in patients with acute respiratory failure and severe hypoxemia: systematic review and meta-analysis. Intensive Care Med. 2010;36(4):585-99. doi: https:// doi.org/10.1007/s00134-009-1748-1.

9. Guérin C, Reignier J, Richard JC, Beuret P, Gacouin A, Boulain $T$, et al. PROSEVA Study Group. Prone positioning in severe acute respiratory distress syndrome. N Engl J Med. 2013;368(23):2159-68. doi: 10.1056/ NEJMoa1214103

10. Arksey H, O'Malley L. Scoping studies: towards a methodological framework. Int J Soc Res Meth. [Internet]. 2005 [cited Jul 14, 2020];8(1):19-32. Available from: https://www.york.ac.uk/inst/spru/pubs/ pdf/Scopingstudies.pdf 
11. Peters MDJ, Godfrey CM, McInerney $P$, Soares $C B$, Khalil H, Parker D. The Joanna Briggs Institute reviewers' manual 2015: methodology for JBI scoping reviews. [Internet]. Adelaide: JBI; 2015 [cited Jul 14, 2020]. Available from: http://joannabriggs.org/assets/ docs/ sumari/Reviewers-Manual_Methodology-for-JBI-ScopingReviews_2015_v2.pdf

12. Elkattawy S, Noori M. A case of improved oxygenation in SARS-CoV-2 positive patient on nasal cannula undergoing prone positioning, Respir Med Case Rep. 2020;30. doi: https://doi.org/10.1016/j. rmcr.2020.101070

13. Jin $Y$, Cai $L$, Cheng $Z$, Cheng $H$, Deng $T$, Fan $Y$, et al. A rapid advice guideline for the diagnosis and treatment of 2019 novel coronavirus (2019-nCoV) infected pneumonia (standard version). Mil Med Res. 2020;7:4. doi: https:// doi.org/10.1186/s40779-020-0233-6

14. Government of Canada. Clinical management of patients with moderate to severe COVID-19 - Interim guidance. [Internet]. 2020 [cited Jul 14, 2020]. Available from: https://www.canada.ca/en/public-health/services/ diseases/2019-novel-coronavirus-infection/clinicalmanagement-covid-19.html

15. Arabi YM, Fowler R, Hayden FG. Critical Care Management of Adults With Community-Acquired Severe Respiratory Viral Infection. Intensive Care Med. 2020;46(2):315-28. doi: https://doi.org/10.1007/ s00134-020-05943-5

16. Piva S, Filippini M, Turla F, Cattaneo S, Margola A, Fulviis $S$. Clinical presentation and initial management critically ill patients with severe acute respiratory syndrome coronavirus 2 (SARS-CoV-2) infection in Brescia, Italy. J Crit Care. 2020;14(58):29-33. doi: https://doi.org/10.1016/j.jcrc.2020.04.004

17. Associação Brasileira de Fisioterapia Cardiorrespiratória e Fisioterapia em Terapia Intensiva. Posição prona no tratamento da insuficiência respiratória aguda na covid-19. [Internet]. São Paulo: ASSOBRAFIR; 2020 [Acesso 14 jul 2020]. Disponível em: https:// assobrafir.com.br/wp-content/uploads/2020/03/ ASSOBRAFIR_COVID-19_PRONA.v3-1.pdf

18. Bamford P, Bentley A, Dean J, Whitmore D, Wilson-Baig N. ICS Guidance for Prone Positioning of the Conscious COVID Patient 2020. [Internet]. London: Intensive Care Society; 2020 [cited Jul 14, 2020]. Available from: https://emcrit.org/wp-content/ uploads/2020/04/2020-04-12-Guidance-for-consciousproning.pdf

19. Ghelichkhani P, EsmaeilI M. Prone Position in Management of COVID-19 Patients; a Commentary. Arch Acad Emerg Med. [Internet]. 2020 [cited Jul 14, 2020];8(1):e48. Available from: https://www.ncbi.nlm. nih.gov/pmc/articles/PMC7158870/
20. Lazzeri M, Lanza A, Bellini R, Bellofiore A, Cechetto S, Colombo $A$, et al. Respiratory physiotherapy in patients with COVID-19 infection in acute setting: a Position Paper of the Italian Association of Respiratory Physiotherapists (ARIR). Monaldi Arch Chest Dis. 2020;90(1). doi: https://doi.org/10.4081/monaldi.2020.1285

21. Silverthorn RA. Strategies for the Management of Acute Respiratory Distress Syndrome Associated with SARS-CoV-2: A Review of Current Literature. [Internet]. 2020 [cited July 14, 2020]. Available from: https://www. researchgate.net/publication/340793837_Strategies_ for_the_Management_of_Acute_Respiratory_Distress_ Syndrome_Associated_with_SARS-CoV-2_A_Review_of_ Current_Literature

22. Alhazzani W, Møller MH, Arabi YM, Loeb M, Gong MN, Fan $E$, et al. Surviving Sepsis Campaign: guidelines on the management of critically ill adults with Coronavirus Disease 2019 (COVID-19). Intensive Care Med. 2020;46(5):854-87. doi: https://doi.org/10.1007/ s00134-020-06022-5

23. Morales FB, Bermúdez ZV. Guía de cuidados de enfermería para el decúbito prono en Síndrome de Distress Respiratorio Agudo asociado a COVID-19: Revisión Integrativa. Rev Med Costa Rica. [Internet]. 2020 [Acceso 14 jul 2020];85(629):58-67. Disponible en: http://www.revistamedicacr.com/index.php/rmcr/ article/view/293/270

24. Web of Science Group. Research in Brazil: funding excellence analysis prepared on behalf of CAPES by the Web of Science Group. [Internet]. 2019 [cited Jul 14, 2020]. Available from: https://jornal.usp.br/wp-content/ uploads/2019/09/ClarivateReport_2013-2018.pdf 25. Santos WM, Secoli SR, Püschel VAA. The Joanna Briggs Institute approach for systematic reviews. Ver. Latino-Am. Enfermagem. 2018;26:e3074. doi: https:// doi.org/10.1590/1518-8345.2885.3074

26. Okuno MF, Belasco A, Barbosa D. Evolução da pesquisa em Enfermagem até a prática baseada em evidências. In: Barbosa D, Taminato M, Fram D, Belasco A. Enfermagem baseada em evidências. [Internet]. São Paulo: Atheneu; 2014 [Acesso 14 jul 2020]. p. 1-7. Disponível em: https://www.semanticscholar.org/paper/ Evolu\%C3\%A7\%C3\%A3o-da-Pesquisa-em-Enfermagemat\%C3\%A9-a-Pr\%C3\%A1tica-em-Fernanda-Okuno/ a23954c4a0a42a1054b 91e09095ca88aa0e49104

27. Pérez Nieto OR, López EIZ, Gutiérrez MAC, Orozco $\mathrm{RC}$, Uribe AFF, Fermín JL, et al. Management protocol for COVID-19. Med Crit. 2020;34(1):43-52. doi: https:// dx.doi.org/10.35366/93280

28. Mitchell D, Seckel M. Acute Respiratory Distress Syndrome and Prone Positioning. AACN Adv Crit Care. 2018;29(4):415-25. doi: https://dx.doi.org/10.4037/ aacnacc2018161 
29. Associação de Medicina Intensiva Brasileira. Orientações sobre o manuseio do paciente com pneumonia e insuficiência respiratória devido a infecção pelo Coronavírus (SARS-CoV-2) - Versão n.03/2020. [Internet]. 2020 [Acesso 14 jul 2020]. Disponível em: https://www.amib.org.br/fileadmin/user_upload/ amib/2020/marco/29/Orientacoes_sobre_o_manuseio_ do_paciente_com_pneumonia_e_insuficiencia_ respiratoria_devido_a_infeccao_pelo_Coronavirus_ SARS-CoV-2_-_Versao_n.032020.pdf

30. Gao L, Yang L, Li X, Chen J, Du J, Bai X, Yang X. The use of a logistic regression model to develop a risk assessment of intraoperatively acquired pressure ulcer. J Clin Nurs. 2018;27(15-16):2984-92. doi: https://doi. org/10.1111/jocn. 14491

31. Luo $\mathrm{M}$, Long $\mathrm{XH}, \mathrm{Wu} \mathrm{JL}$, Huang SZ, Zeng Y. Incidence and Risk Factors of Pressure Injuries in Surgical Spinal Patients: A Retrospective Study. J Wound Ostomy Continence Nurs. 2019;46(5):397 $\square$ 400. https://dx.doi. org/10.1097/WON.0000000000000570

32. Saran S, Gurjar M, Kanaujia V, Ghosh PS, Gupta A, Mishra $P$, et al. Effect of Prone Positioning on Intraocular Pressure in Patients With Acute Respiratory Distress Syndrome. Crit Care Med. 2019;47(9):e761-e766. doi: https://doi.org/10.1097/CCM.0000000000003893

33. Biscevic M, Sehic A, Biscevic S, Gavrankapetanovic I, Smrke B, Vukomanovic D, et al. Kyphosis - A risk factor for positioning brachial plexopathy during spinal surgeries. Acta Orthop Traumatol Turc. 2019;53(3):199202. doi: https://dx.doi.org/10.1016/j.aott.2019.02.002 34. Aisu Y, Hori T, Kato S, Ando Y, Yasukawa D, Kimura $Y$, et al. Brachial plexus paralysis after thoracoscopic esophagectomy for esophageal cancer in the prone position: a thought-provoking case report of an unexpected complication. Int J Surg Case Rep. 2019;55:11-4. doi: https://doi.org/10.1016/j. ijscr.2018.12.001

35. Saiwai H, Okada S, Kawaguchi KI, Saito T, Hayashida $M$, Matsushita $A$, et al. Prone position surgery for a professional sumo wrestler with thoracic ossification of the posterior longitudinal ligament resulting in intraoperative brachial plexus injury by hypertrophic pectoral muscles. J Clin Neurosci. 2019;63:227-30. doi: https://doi.org/10.1016/j.jocn.2019.01.047

36. Yamamoto N, Ishii A, Miyashita T, Goto T. Airway management strategy for accidental tracheal extubation in the prone position: A simulation study. J Clin Anesth. 2020;63:109786. doi: https://dx.doi.org/10.1016/j. jclinane.2020.109786

37. Barrasa H, Rello J, Tejada S, Martín A, Balziskueta G, Vinuesa $C$, et al. SARS-CoV-2 in Spanish Intensive Care Units: Early experience with 15-day survival in Vitoria. Anaesth Crit Care Pain Med. 2020;S2352-
5568(20):30064-3. doi: https://dx.doi.org/10.1016/j. accpm.2020.04.001

38. Gaszynski T. Algorithm for management of sudden unexpected extubation in patient positioned in prone position. Anaesthesiol Intensive Ther. 2020;40505. doi: https://dx.doi.org/10.5114/ait.2020.94795

39. Jérome L, Diabira S, Gentili M. Airway management with a laryngeal mask after accidental tracheal extubation of a patient in prone position for surgical kyphoplasty. Anaesthesiol Intensive Ther. 2020;40592. doi: https:// dx.doi.org/10.5114/ait.2020.95169

40. Yoon HK, Lee HC, Chung J, Park HP. Predictive Factors for Hypotension Associated With Supine-to-Prone Positional Change in Patients Undergoing Spine Surgery. J Neurosurg Anesthesiol. 2020;32(2):140-6. doi: https:// dx.doi.org/10.1097/ANA.0000000000000565

41. Manohar N, Ramesh VJ, Radhakrishnan M, Chakraborti D. Haemodynamic changes during prone positioning in anaesthetised chronic cervical myelopathy patients. Indian J Anaesth. 2019;63(3):212-7. doi: https://dx.doi.org/10.4103/ija.IJA_810_18

42. Guo J, Huang Z, Lin L, Lv J. Coronavirus disease 2019 (COVID-19) and cardiovascular disease: a viewpoint on the potential influence of angiotensin-converting enzyme inhibitors/angiotensin receptor blockers on onset and severity of severe acute respiratory syndrome coronavirus 2 infection. J Am Heart Assoc. 2020; 9. doi: https://dx.doi.org/10.1161/JAHA.120.016219

43. Adams E, Mousa A. Achieving a Popliteal Venous Access for RRT in Critically Ill COVID-19 Patient in Prone position. J Vascular Surg Cases Innov Tech. 2020;6(2):266-8. doi: https://dx.doi.org/10.1016/j. jvscit.2020.04.003

44. Ananias MANB, Cambraia AA, Calderaro DC. Effect of prone position on respiratory mechanics and gas exchanges in patients with severe ARDS. Rev Med Minas Gerais. 2018;28(Supl 5):e-S2805-28.doi: http://www. dx.doi.org/10.5935/2238-3182.20180140

45. Paiva KCA, Beppu OS. Prone position. J Bras Pneumol. [Internet]. 2005 [cited June 6, 2020];31(4):332-40. doi: http://dx.doi.org/10.1590/S1806-37132005000400011 46. Sicuso C, Balzarini L, Lutman RF, Profili M, Lanza E, Politi LS. Supine vs. prone chest CT in a COVID-19 patient during mechanical ventilation. [Internet]. 2020 [cited Jul 14, 2020]. Available from: https://www. eurorad.org/case/16673

47. Munshi L, Del Sorbo L, Adhikari N, Hodgson CL, Wunsch $\mathrm{H}$, Meade MO, et al. Prone Position for Acute Respiratory Distress Syndrome. A Systematic Review and Meta-Analysis. Ann Am Thorac Soc. 2017;14(Suppl 4):280-8. doi: https://doi.org/10.1590/s1980$220 \times 2016048803251$ 
48. American Association for Respiratory Care. Guidance Document. [Internet]. 2020 [cited Jul 14, 2020]. Available from: https://www.aarc.org/wpcontent/uploads/2020/03/guidance-document-SARSCOVID19.pdf

49. Dondorp AM, Hayat M, Aryal D, Beane A, Schultz MJ. Respiratory Support in COVID-19 Patients, with a Focus on Resource-Limited Settings. Am J Trop Med Hyg. 2020;102(6):1191-7. doi: http://dx.doi.org/10.4269/ ajtmh.20-0283

50. Rocco IS, Gomes WJ, Viceconte M, Bolzan DW, Moreira RSL, Arena R, et al. Cardiovascular involvement in COVID-19: not to be missed. Braz J Cardiovasc Surg. 2020:1-9. doi: http://dx.doi.org/10.21470/1678-97412020-0224

51. Fernandez R, Trenchs X, Klamburg J, Castedo J, Serrano JM, Besso G, et al. Prone positioning in acute respiratory distress syndrome: a multicenter randomized clinical trial. Intensive Care Med. 2008;34:1487-91. doi: http://dx.doi.org/10.1007/s00134-008-1119-3

52. Carsetti A, Paciarini AD, Marini B, Pantanetti S, Adrario E, Donati A. Prolonged prone position ventilation for SARS-CoV-2 patients is feasible and effective. Crit Care. 2020;24:225. doi: http://dx.doi. org/10.1186/s13054-020-02956-w

53. Setten M, Plotnikow G, Accoce M. Prone position in patients with acute respiratory distress syndrome. Rev Bras Ter Intensiva. 2016;28(4):452-62. doi: http:// dx.doi.org/10.5935/0103-507x.20160066

54. Hodes A, Evans LE, Alhazzani W, Levy MM, Antonelli M, Ferrer $\mathrm{R}$, et al. Surviving sepsis campaign: International Guidelines for Management of Sepsis and Septic Shock: 2016. Intensive Care Med. 2017;45(3):486-552. doi: http://dx.doi.org/10.1097/CCM.0000000000002255

55. Fan E, Del Sorbo L, Goligher EC, Hodgson CL, Munshi L, Walkey AJ, et al. American Thoracic Society, European Society of Intensive Care Medicine, and Society of Critical Care Medicine. An official American Thoracic Society/European Society of Intensive Care Medicine/ Society of Critical Care Medicine Clinical Practice guideline: Mechanical ventilation in adult patients with acute respiratory distress syndrome. Am J Respir Crit Care Med. 2017;195:1253-63. doi: http://dx.doi. org/10.1164/rccm.201703-0548ST
56. Véras JB, Martinez BP, Gomes Neto $M$, Saquetto MB, Conceição CS, Silva CM. Effects of prone position on patients with acute respiratory distress syndrome: a systematic review. Rev Pesq Fisioter. 2019;9(1):12938. doi: http://dx.doi.org/10.17267/2238-2704rpf. v9i1.2175v9i1.2175

57. Pereira-Rodríguez JE, Quintero-Gomez JC, Otilio LF, Sharon WSS, Ximena VB. Ventilatory support in sarsvoc-2 during intensive Therapy. MedRxiv. 2020. doi: https://doi.org/10.1101/2020.05.14.20098608
Received: July $14^{\text {th }} 2020$ Accepted: Aug $10^{\text {th }} 2020$

Associate editor: Andrea Bernardes

Copyright $($ C) 2021 Revista Latino-Americana de Enfermagem This is an Open Access article distributed under the terms of the Creative Commons (CC BY).

This license lets others distribute, remix, tweak, and build upon your work, even commercially, as long as they credit you for the original creation. This is the most accommodating of licenses offered. Recommended for maximum dissemination and use of licensed materials. 